\title{
STUDY OF THE ANXIOLYTIC ACTIVITY OF ETHANOLIC EXTRACT OF ROOT OF ACORUS CALAMUSIN ALBINO MICE USING MIRRORED CHAMBER
}

\author{
SHIPRA KAUSHIK*, HARSHWARDHAN \\ Department of Pharmacology, GS Medical College and Hospital, Pilkhuwa, Uttar Pradesh, India. Email: shipra014@gmail.com
}

Received: 02 June 2021, Revised and Accepted: 12 July 2021

ABSTRACT

Objective: Anxiety is classified as a form of sub-acute or chronic fear. The root of Acorus calamus has been traditionally used as an anxiolytic. The aim of the study is to assess the anxiolytic activity of ethanolic extract of the root of A. calamus (EEAC) by Mirrored Chamber Test on Albino mice.

Methods: Albino mice of either sex were taken and divided into five groups, each consisting of 5 mice. One group was used as control, one as standard (Diazepam), and three as test groups treated with 100, 200 and $400 \mathrm{mg} / \mathrm{kg}$ of EEAC.The drugs, i.e., $10 \mathrm{ml} / \mathrm{kg}$ of Normal saline for control, Diazepam $2 \mathrm{mg} / \mathrm{kg}$ (standard), and 100, 200 and $400 \mathrm{mg} / \mathrm{kg}$ EEAC (test groups) were injected intraperitoneally (i.p.),30 min before placing them in the center of the mirrored chamber.Latency to enter the chamber, number of entries in 5 min,and total time spent in the chamber during 5 mintest period were compared in each group. Data were statistically analyzed by one-way analysis of variance followed by multiple Dunnett's test.

Results: EEAC showed significant increase in all the parameters for the doses of 100, 200 and $400 \mathrm{mg} / \mathrm{kg}$ in a dose dependent manner.

Conclusion: EEAC has anxiolytic activity.

Keywords: Anxiolytic, Mirrored chamber, Diazepam, Acorus calamus.

(C) 2021 The Authors. Published by Innovare Academic Sciences Pvt Ltd. This is an open access article under the CC BY license (http://creativecommons.org/ licenses/by/4.0/) DOI: http://dx.doi.org/10.22159/ajpcr.2021v14i9.42278. Journal homepage: https://innovareacademics.in/journals/index.php/ajpcr

\section{INTRODUCTION}

Anxiety disorders, the most prevalent psychiatric illness in the general community, are present in $15-20 \%$ of medical clinic patients. Anxiety, defined as a subjective sense of unease, dread, or foreboding, can indicate a primary psychiatric condition or can be a component of, or reaction to, a primary medical disease [1]. Anxiety is a cardinal symptom of many psychiatric disorders and an almost inevitable component of many medical and surgical conditions. Indeed, it is a universal human emotion, closely allied with appropriate fear and presumably serving psychobiological adaptive purposes [2]. The word anxiety is derived from the Latin "anxietas" (to choke, throttle, trouble, and upset) and encompasses behavioral, affective, and cognitive responses to the perception of danger. Anxiety is a normal human emotion. In moderation, anxiety stimulates an anticipatory and adaptive response to challenging or stressful events. In excess, anxiety destabilizes the individual, and dysfunctional state results. Anxiety is considered excessive or pathological when it arises in the absence of challenge or stress when it is out of proportion to the challenge or stress in duration or severity, when it results in significant distress, and when it results in psychological, social, occupational, biological, and other impairment [3]. The principal components of anxiety are psychological (tension, fears, difficulty in concentration, apprehension), and somatic (tachycardia, hyperventilation, palpitation, tremor, and sweating). Fatigue and sleep disturbances are common. Sympathomimetic symptoms of anxiety are both a response to a central nervous system state and reinforcement of further anxiety [4].

Benzodiazepines, being major class of compounds used for the treatment of anxiety, present a narrow margin of safety between the anxiolytic effect and unwanted side effects, has prompted researchers to evaluate new compounds especially plant-based drugs having less undesirable effects [5]. The importance of the traditional system of medicine and of certain medicinal practices has now been recognized all over the world. Today, it is required to have an intelligent and pragmatic approach to evaluate selective drugs of herbal origin [6].
Acorus calamus is commonly known as sweet flag in English and Vasa bach in Hindi.A. calamus is a source of essential oil, which is responsible for the medicinal and insecticidal properties. Extractives of different parts of $A$. calamus and calamus oil are widely in traditional systems of medicines for a number of ailments such as antimicrobial, anti-itching, anticonvulsant, antianxiety, antiviral, antiulcer, antispasmodic, antiinflammatory, anticancer, nootropic, anti-schizophrenia, insecticide, tranquilizer, and anti-asthmatic [7]. Different parts of the plant showed the presence of large number of phenylpropanoids, sesquiterpenes, and monoterpenes as well as xanthone glycosides, flavones, lignin, lignans, steroids, and inorganic constituents. Alcoholic extracts of the triploid A. calamus were characterized by a higher percentage of b-asarone $(11 \%)$, which was the main compound [8]. In spite of traditional use, the pharmacology of its different parts has not yet been explored scientifically. As such, the present investigation was carried out to evaluate the anxiolytic activity of the ethanolic extract of the root of A. calamus (EEAC) in experimental animal models.

\section{METHODS}

\section{Plant}

Root of A. calamuswere collected and authenticated by Dr. M. Islam, Professor, Department of Life Science, Dibrugarh University.A voucher specimen(No. DU/LS/219) was deposited at Dibrugarh University.

\section{Preparation of plant extract}

The required amount of roots of $A$. calamus were collected and dried at room temperature. The dried roots were ground into powder separately. Sufficient amount of powdered roots were moistened with $95 \%$ ethyl alcohol and allowed to remain for 6 hours in a percolator. When the liquid began to drop from the percolator, the orifice was closed and the content was allowed to macerate for $24 \mathrm{~h}$. After $24 \mathrm{~h}$, it was allowed to percolate slowly, a rate not exceeding $1 \mathrm{ml} / \mathrm{min}$ and the solution was collected in Petri dishes. Alcohol was allowed to evaporate at room temperature. When the extract got completely dried, it was scrapped out, weighed, and stored and the yield at the end of extraction was found to be $80 \mathrm{~g}$ [9]. 
Drugs

Diazepam obtained from Ranbaxy Laboratories, New Delhi.

\section{Animal}

Healthy Albino mice of either sex were taken from Central Animal House, Assam Medical College (Registration no. 634/02/a/CPCSEA dated May 19, 2002). The animals were housed in standard cages and maintained under normal room temperature. The rats were maintained on standard animal diet of Bengal gram, wheat, maize, and carrot in sufficient quantity for the entire period of the experiment. Water was given ad libitum during the entire period of the experiment.

\section{Acute oral toxicity studies}

Acute oral toxicity test was done according to the OECD guidelines 425 [10]. Albino mice of either sex were used.A total of five animals were used. After overnight fasting, they received a single oral dose ( $2000 \mathrm{mg} / \mathrm{kg}$ body weight) of EEAC. Then food was withheld for further 3-4 h. Animals were observed individually at least once during the first $30 \mathrm{~min}$ after dosing, periodically during the first $24 \mathrm{~h}$ (with special attention during the first $4 \mathrm{~h}$ ), and daily thereafter for a period of 14 days. At the end of the study, the animals were observed for general toxic signs, morphological behaviour and mortality [11].

\section{Preparation of drug doses}

1. Vehicle: Normal saline $10 \mathrm{ml} / \mathrm{kg}$ was used in control group

2. Test Drugs: 100,200 and $400 \mathrm{mg} / \mathrm{kg}$ of EEAC were prepared with normal saline as the solvent

3. Standard Drugs: Diazepam $2 \mathrm{mg} / \mathrm{kg}$ prepared with normal saline.

\section{Experimental design}

Mirrored chamber test

Procedure

Healthy albino mice of either sex were taken and divided into five groups, each consisting of 5 mice. One group was used as control, one as standard Diazepam $2 \mathrm{mg} / \mathrm{kg}$ ) and three as test groups treated with 100,200 and $400 \mathrm{mg} / \mathrm{kg}$ of EEAC

The animals were placed individually in the chamber of mirrors at a fixed corner and the stopwatch started and following parameters noted for $5 \mathrm{~min}$ :

a. Latency to enter the chamber, i.e., the time in seconds for the first entry into the chamber of mirrors

b. Number of entries in $5 \mathrm{~min}$

c. Total time in seconds spent in the chamber during the 5 min test period.

The criterion for entry into the chamber is all four paws being placed on the floor panel of the mirrored chamber. The drugs, i.e., $10 \mathrm{ml} / \mathrm{kg}$ of Normal saline for control, 100, 200 and $400 \mathrm{mg} / \mathrm{kg}$ EEAC, and Diazepam $2 \mathrm{mg} / \mathrm{kg}$ were injected i.p., $30 \mathrm{~min}$ before placing them in center of the mirrored chamber.

The chamber was cleaned after every test to eliminate potential cues such as excreta and urine droplets or spots. The time spent with each entry was calculated by dividing the total time spent with number of entries [12]

\section{Statistical analysis}

The statistical significance between groups was analyzed separately using One-way analysis of variance (ANOVA), followed by Dunnett's multiple comparison test. The significance was expressed by p-values, as mentioned in the tables. $\mathrm{p}<0.05$ were considered as significant.

\section{RESULTS}

\section{Acute toxicity test}

There was no mortality and no sign-symptom of toxicity reported among the animals up to $2000 \mathrm{mg} / \mathrm{kg}$. So the $\mathrm{LD}_{50}$ was calculated $>2000 \mathrm{mg} / \mathrm{kg}$ body weight.
Table 1: Effect of EEAC on latency to enter mirror chamber, number of entries in 5 min and time spent in mirror chamber

\begin{tabular}{lcccc}
\hline $\begin{array}{l}\text { Treatment } \\
\text { (mg/Kg IP) }\end{array}$ & $\begin{array}{c}\text { Number } \\
\text { of } \\
\text { Animals }\end{array}$ & $\begin{array}{c}\text { Latency } \\
\text { to enter } \\
\text { Chamber } \\
\text { (Sec } \pm \text { SEM) }\end{array}$ & $\begin{array}{c}\text { Number } \\
\text { of Entries } \\
\text { in 5 min } \\
\text { (Sec } \pm \text { SEM) }\end{array}$ & $\begin{array}{c}\text { Time Spent } \\
\text { in the Mirror } \\
\text { Chamber } \\
\text { (S } \pm \text { SEM) }\end{array}$ \\
\hline $10 \mathrm{ml} / \mathrm{kg}$ & 5 & $286.0 \pm 9.8$ & $0.40 \pm 0.24$ & $2.60 \pm 1.94$ \\
Normal Saline & 5 & $170.60 \pm 9.35^{\mathrm{a}}$ & $3.6 \pm 0.51^{\mathrm{a}}$ & $31.40 \pm 5.81^{\mathrm{a}}$ \\
EEAC100 & 5 & $148.6 \pm 5.8^{\mathrm{a}}$ & $5.4 \pm 0.51^{\mathrm{a}}$ & $46.0 \pm 4.6^{\mathrm{a}}$ \\
EEAC200 & 5 & $126.4 \pm 6.4^{\mathrm{a}}$ & $6.7 \pm 0.25^{\mathrm{a}}$ & $54.2 \pm 4.2^{\mathrm{a}}$ \\
EEAC400 & 5 & $30.60 \pm 3.72^{\mathrm{a}}$ & $8.40 \pm 0.51^{\mathrm{a}}$ & $72.80 \pm 4.35^{\mathrm{a}}$ \\
$\begin{array}{l}\text { Diazepam } \\
\text { 2mg/kg }\end{array}$ & 5 & 189.1 & 55.38 & 44.15 \\
One Way & $\mathrm{F}$ & & & 4,16 \\
ANOVA & df & 4,16 & 4.16 & $<0.01$ \\
\hline
\end{tabular}

$\mathrm{n}=5$ in each group; all values were expressed in mean \pm SEM $-{ }^{\mathrm{a}} \mathrm{p}<0.01$ is significant when compared to control (ANOVA followed by Dunnet's multiple comparision test)

\section{EFFECT OF EEAC ON LATENCY TO ENTER THE CHAMBER IN MC TEST}
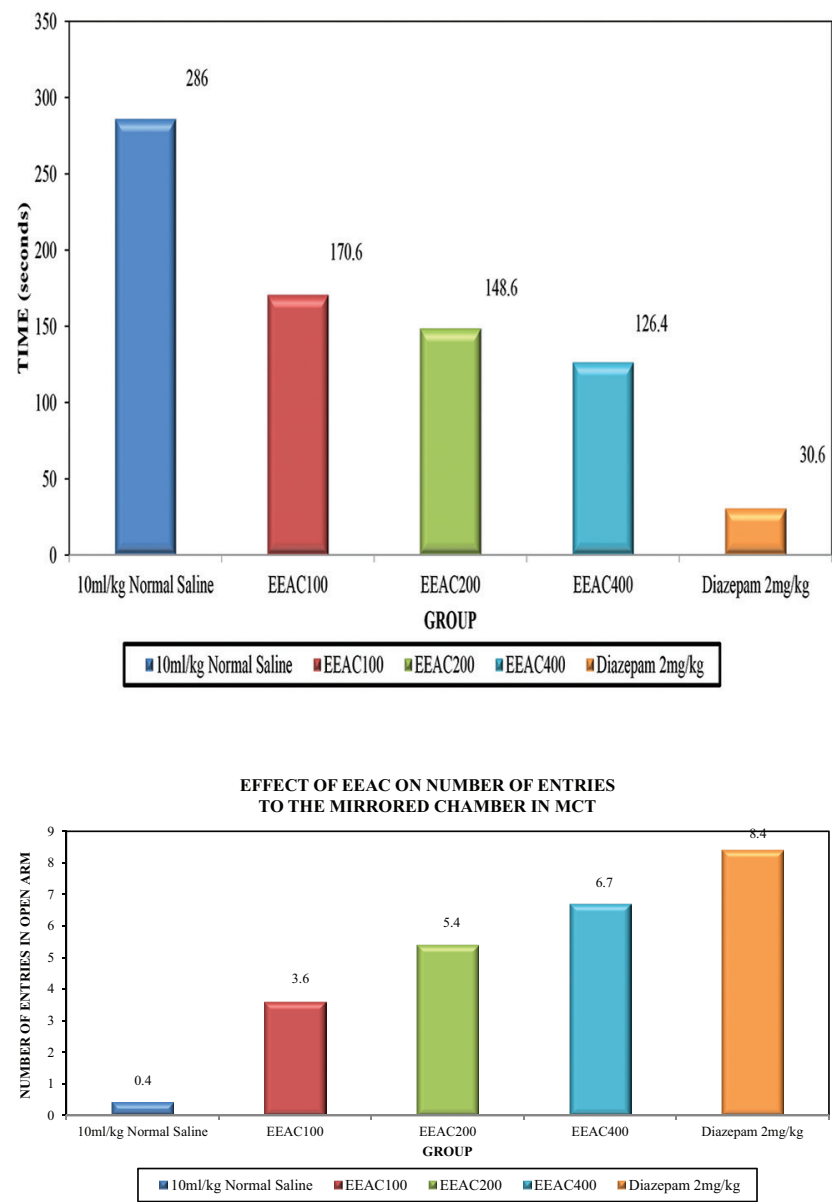

Mirrored chamber model

The latency to enter the Mirrored Chamber for the animals in the test groups of EEAC for the doses of 100, 200, and $400 \mathrm{mg} / \mathrm{kg}$ was significantly reduced as compared to the control group in a dose-dependent manner. There was significant increase in the number of entries and time spent in the mirror chamber for test doses of EEAC when compared to the control group in a dose-dependent manner. 
EFFECT OF EEAC ON TIME SPENT IN MIRRORED CHAMBER IN MCT

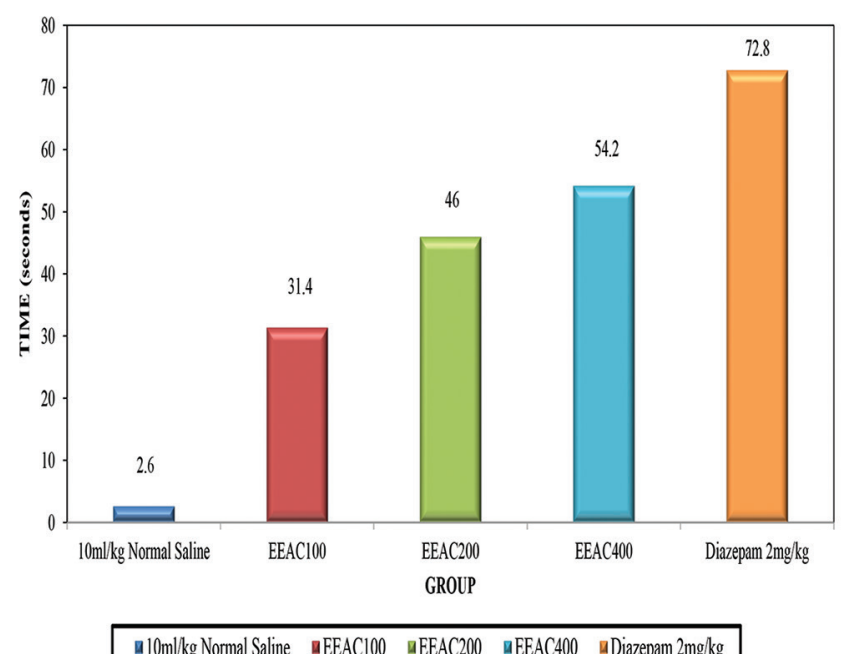

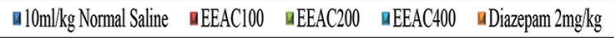

\section{DISCUSSION}

The present study was undertaken to evaluate the anxiolytic activity of the EEACin experimental animal models. The experimental design selected was Mirrored Chamber model. The Mirrored chamber test is the most popular and valid animal model for measuring anxiety by investigating aspects of physiological and pharmacological behavior [13].

Many animal species exhibit approach-avoidance response upon placement of a mirror within their environment. In order to identify new behavioral measures with qualitatively different responses, a mirrored chamber apparatus was developed for which mice show an extended latency to enter. Novel stimulation evokes both exploration and anxiety and thereby generates an approach-avoidance conflict behavior. It is hypothesized that distortion of the appearance of a readily traversed environment by a compartment constructed of mirrored glass might produce an aversion to entry. The response to an apparent animal reflected in the mirror might also be a source of anxiety. This apparatus is widely used for the evaluation of anxiolytic agents belonging to chemically different class [12].

In the present study, the latency to enter the mirrored chamber in the control group A was $286.0 \pm 9.8 \mathrm{~s}$, for the test groups $\mathrm{B}_{1,} \mathrm{~B}_{2,} \mathrm{~B}_{3}$ viz. EEAC 100,200 and $400 \mathrm{mg} / \mathrm{kg}$ were $170.60 \pm 9.35,148.6 \pm 5.8$ and $126.4 \pm$ $6.4 \mathrm{~s}$ respectively and for standard group $\mathrm{C}$ was $30.60 \pm 3.72 \mathrm{~s}$. The number of entries to the mirrored chamber in the control group was $0.40 \pm 0.24 \mathrm{~s}$ in the test groups of EEAC 100,200 and $400 \mathrm{mg} / \mathrm{kg}$ were $3.6 \pm 0.51,5.4 \pm 0.51$ and $6.7 \pm 0.25 \mathrm{~s}$, respectively, and for the standard group was $8.40 \pm 0.51 \mathrm{~s}$. The time spent inside the mirrored chamber for the control group was $2.60 \pm 1.94 \mathrm{~s}$, for the test groups of EEAC 100,200 and $400 \mathrm{mg} / \mathrm{kg}$ were $31.40 \pm 5.81,46.0 \pm 4.6$ and $54.2 \pm 4.2 \mathrm{~s}$, respectively, and for the standard group was $72.80 \pm 4.35 \mathrm{~s}$.

Similar were the findings of Reddy and Kulkarni (1997) to study the differential anxiolytic effects of neurosteroids in the mirrored chamber behavior test in mice.In this model, EEAC showed significant increase in all the parameters for the doses of 100,200 , and $400 \mathrm{mg} / \mathrm{kg}$ in a dosedependent manner.

The present study demonstrated that the EEAC showed significant anxiolytic activity thereby establishing its traditional use in conditions having anxiety. However, further studies and development of more purified product of root of A. calamus are required for proper clinical use.

\section{ACKNOWLEDGMENT}

We are thankful to Dr. M. Islam, Professor, Life Science, Dibrugarh University for his help in taxonomical identification.

\section{CONFLICTS OF INTEREST}

Nil.

\section{AUTHORS' CONTRIBUTIONS}

Dr. Shipra Kaushik contributed in the drafting of protocol, conducting the experiment, collection, and analysis of data, drafting of the manuscript. Both the authors read and approve the final manuscript.

\section{AUTHORS' FUNDING}

Nil.

\section{REFERENCES}

1. Reus VI. Psychiatric disorders. Mental disorders. In: Kasper D, Braunwald E, Fauci A, Hauser SL, Longo L, Jameson JL, editors. Harrison's Principles of Internal Medicine. $17^{\text {th }}$ ed. New York: The McGraw-Hill Companies, Inc.; 2008, p. 2717-23.

2. Baldessarini RJ. Drug therapy of depression and anxiety disorders. In: Brunton LL, Lazo JS, Parker KL, editors. Goodman and Gilman's the Pharmacological Basis of Therapeutics. 12 $2^{\text {th }}$ ed. New York: The McGraw-Hill Companies, Inc.; 2011. p. 583-607.

3. Trivedi JK, Gupta PK. An overview of Indian research in anxiety disorders. Indian J Psychiatry 2010;52 Suppl 1:S210-8.

4. Elisendranth SJ, Lichtmacher KE. Psychiatric disorders. In: McPhee SJ, Papadakis MA, Tierney LM, editors. Current Medical Diagnosis and Treatment. $47^{\text {th }}$ ed. New York: The McGraw-Hill Companies, Inc.; 2008. p. 807-902.

5. Kaur D, Kaur D, Bains N, Chopra A, Arora P. Anti-anxiety evaluation of extracts of stigma maydis (corn silk). Int J Pharm Pharm Sci 2015;8:309-12. Available from: https://www.innovareacademics.in/ journals/index.php/ijpps/article/view/6943.

6. Vyawahare NS, Khandelwal AR, Batra VR, Nikam AP. Herbal anticonvulsants.J Herbal Med Toxicol 2007;1:9-14.

7. Elaya RA, Vijayalakshmi M, Devalarao G. Acorus calamus Linn, chemistry and biology. Res J Pharmacol 2009;2:256-61.

8. Meena AK, Rao MM, Singh A, Kumari S. Physicochemical and preliminary phytochemical studies on the rhizome of Acorus calamus Linn. Int J Pharm Pharm Sci 2010;2:130-1.

9. The Chemist and Druggist. Extract Liquid, Pharmaceutical Formulas PF. $11^{\text {th }}$ ed., Vol. 1. London: The Chemist and Druggist; 1950. p. 183-6.

10. OECD Guideline (Organization for Economic Corporation and Development). OECD Guidelines for Testing of Chemicals, Health Effects, Test No. 425, Acute Oral Toxicity. France: OECD Publishing; 2006. p. 1-27. Available from: http://www.oecdbookshop.org/oecd/ index. [Last accessed on 2011 Aug 02].

11. Ghosh MN. Toxicity studies. In: Fundamentals of Experimental Pharmacology. $5^{\text {th }}$ ed. Kolkata, India: Hilton and Company; 2008. p. 173-8.

12. Kulkarni SK. Experiments on intact preparations. In: Pharmacology of CNS. Hand Book of Experimental Pharmacology. $3^{\text {rd }}$ ed. New Delhi: Vallabh Prakashan; 2005. p. 131-9.

13. Yende SR, Harle UN, Ittadwar AM. Anxiolytic activity of marine macroalgae sargassum ilicifolium and padina tetrastomatica in mice. Int J Pharm Pharm Sci 2016;8:97-101. Available from: https://www. innovareacademics.in/journals/index.php/ijpps/article/view/10582. 